\title{
Wpływ wybranych cytokin na uszkodzenie narządów w toczniu rumieniowatym układowym
}

\author{
Influence of selected cytokines on organ damage in systemic lupus erythematosus
}

\author{
Łukasz Kapłon ${ }^{\bowtie}$, Marek Brzosko ${ }^{凶}$ \\ Pomorski Uniwersytet Medyczny w Szczecinie, Klinika Reumatologii, Chorób Wewnętrznych i Geriatrii, ul. Unii Lubelskiej 1, 71-252 Szczecin \\ Pomeranian Medical University in Szczecin, Department of Rheumatology, Internal Diseases and Geriatrics \\ $\bowtie$ lukaszkaplon89@gmail.com, brzoskom@pum.edu.pl
}

\begin{abstract}
Systemic lupus erythematosus (SLE) is a rheumatic disease with unclear pathogenesis. In the course of this disease a dysfunction of the immune system occurs, which involves the production of autoantibodies and the deposition of immune complexes, which contributes to the damage of various organs. The most commonly involved organs include: kidneys, skin, joints, the eye, respiratory system, and the cardiovascular and nervous systems, both central and peripheral. In recent years there have been reports regarding the role of cytokines in the pathogenesis of various organs' involvement. However, until now it has not been entirely clear which cytokines are responsible for either the stimulation or inhibition of the inflammatory response, which could be helpful in establishing a relationship with the clinical picture. In this article reports are summarized regarding Interleukins 4 , 7, 10, 18 (IL-4, IL-7, IL-10, IL-18) and their relationship with organ involvement in SLE. Interleukin 4 is indicated as a protective
\end{abstract}

cytokine by its role in preventing the development of an autoimmune response. In the case of IL-7, it has a role in increasing the proliferation of autoreactive T-cell clones and the development of the disease. The IL-10, despite its protective effect, is found in patients with SLE at significantly higher concentrations than in the general population and correlates with the SLEDAI disease activity level scale. Interleukin 18 has a pro-inflammatory effect, contributing to damage to tissues and organs. In the serum of patients with SLE significantly higher levels of IL-18 were found than in the control group; there was also a statistically significant positive correlation between serum IL-18 levels and SLEDAI disease activity level scale and anti-dsDNA antibody titers. Increasing levels of serum IL-18 in SLE patients is associated with an increased risk of cardiovascular disease. In addition, IL-18 has an important role in the involvement of the kidneys and skin in SLE patients. Keywords: systemic lupus erythematosus; organ involvement; cytokines.

\begin{abstract}
ABSTRAKT
Toczeń rumieniowaty układowy (TRU) jest chorobą reumatyczną o nie w pełni poznanej patogenezie. W przebiegu tej choroby występuje dysfunkcja układu immunologicznego polegająca na wytwarzaniu autoprzeciwciał i odkładaniu się kompleksów immunologicznych, które przyczyniają się do uszkodzeń różnych narządów. Najczęściej zajęte narządy to: nerki, skóra, układ ruchu, narząd wzroku, układ oddechowy, układ sercowo-naczyniowy oraz nerwowy, zarówno ośrodkowy, jak i obwodowy. W ostatnich latach pojawiły się doniesienia dotyczące roli cytokin w patogenezie zajęcia różnych narządów. Jednakże do tej pory nie jest w pełni jasne, które cytokiny są odpowiedzialne za nasilenie, a które za zmniejszenie odpowiedzi zapalnej, co mogłoby pomóc w ustaleniu związku z obrazem klinicznym. W artykule zestawione zostały doniesienia dotyczące Interleukin (IL) 4, 7, 10, 18 oraz ich związku z zajęciem narządowym w przebiegu TRU. W przypadku IL-4 wskazuje się na ochronną rolę tej cytokiny poprzez zapobieganie rozwojowi odpowiedzi
\end{abstract}

autoimmunologicznej, z kolei IL-7 przypisuje się udział w rozwoju autoreaktywnych klonów limfocytów T oraz rozwoju choroby. Natomiast IL-10, pomimo swojego ochronnego działania, występuje u chorych na TRU w znacznie wyższych stężeniach niż w populacji ogólnej i koreluje ze stopniem aktywności choroby wyrażonej za pomocą skali SLEDAI. Działanie prozapalne ma IL-18, co przyczynia się w konsekwencji do uszkodzenia tkanek i narządów. W surowicy chorych na TRU stwierdza się znacznie wyższe stężenie IL-18 niż w grupie kontrolnej, ponadto wykazano statystycznie istotną dodatnią korelację pomiędzy stężeniem IL-18 w surowicy chorych a stopniem aktywności choroby mierzonym za pomocą skali SLEDAI oraz mianem przeciwciał anty-dsDNA. Wzrastające stężenie IL-18 w surowicy chorych na TRU jest związane ze wzrostem ryzyka sercowo-naczyniowego. Dodatkowo IL-18 przypisuje się rolę w zajęciu nerek oraz skóry u chorych na TRU.

Słowa kluczowe: toczeń rumieniowaty układowy; zajęcie narządowe; cytokiny.

\section{WSTĘP}

Toczeń rumieniowaty układowy (TRU) jest chorobą reumatyczną o nie w pełni poznanej patogenezie. W przebiegu tej choroby występuje dysfunkcja układu immunologicznego polegająca na wytwarzaniu autoprzeciwciał i odkładaniu się kompleksów immunologicznych, które przyczyniają się do uszkodzeń różnych narządów. W zależności od tego, które narządy zostały zajęte, choroba przyjmuje zróżnicowany obraz kliniczny. Najczęściej zajęte narządy to: nerki, skóra, układ ruchu, narząd wzroku, układ oddechowy, układ sercowo-naczyniowy oraz nerwowy, zarówno ośrodkowy, jak i obwodowy. 
Częstsze występowanie wśród kobiet w wieku pokwitania sugeruje udział czynników hormonalnych. Ze względu na zwiększoną częstość występowania u rasy czarnej podejrzewa się również udział czynników genetycznych $[1,2,3]$.

Istotną rolę w patogenezie TRU przypisuje się zaburzeniom układu immunologicznego, tj. wytwarzaniu autoprzeciwciał przez limfocyty B oraz zmniejszeniu klirensu komórek apoptycznych i kompleksów immunologicznych poprzez ograniczenie sprawności m.in. układu dopełniacza $[1,2,3]$. W przebiegu TRU jest wytwarzana szeroka gama przeciwciał skierowanych przeciwko własnym antygenom, jednakże tylko kilka z nich można uznać za typowe dla tej choroby, tj. przeciwciała przeciw dwuniciowemu DNA (anty-dsDNA), przeciw grupie białek powstałych w wyniku splicingu fragmentów małego jądrowego RNP - antygenowi Smith (anty-Sm), przeciw małym rybonukleinom o wysokiej zawartości urydyny - U1-snRNP (anty-RNP) oraz przeciwciała przeciw rybonukleinom zawierających RNA oraz białkom $52 \mathrm{kDa}$ i $60 \mathrm{kDa}$ - (anty-SS-A/Ro) i przeciw fosfoproteinie o ciężarze $48 \mathrm{kDa}$ (anty-SS-B/La) [3].

Za najważniejsze przeciwciała w TRU uznaje się anty-dsDNA i anty-Sm. Obecność tych przeciwciał w podwyższonym mianie jest ujęta w kryteriach klasyfikacyjnych TRU wg American College of Rheumatology z 1982 r. oraz po ich zaktualizowaniu w 1997 r. Wskazuje się na ich szczególną rolę w patogenezie nefropatii toczniowej [4].

\section{ZAJĘCIE NEREK}

Zajęcie nerek w TRU, określane również jako toczniowe zapalenie nerek lub nefropatia toczniowa, jest chorobą zapalną nerek, która może przyjmować różne postacie. Proces zapalny związany z TRU może obejmować kłębuszki nerkowe, cewki, miąższ nerki oraz naczynia nerkowe. Zajęcie nerek w TRU może występować u ok. 60\% chorych [5]. Występuje przeważnie u osób młodych, przed 50. r.ż., częściej u kobiet. Natomiast u mężczyzn zajęcie nerek ma cięższy przebieg. Częstość występowania nefropatii toczniowej różni się w zależności od populacji. Zajęcie nerek częściej występuje u rasy żółtej (55\%), czarnej (51\%), u Latynosów (43\%) niż u rasy kaukaskiej (14\%) [6]. Zajęcie nerek we wczesnej fazie TRU jest związane ze złym rokowaniem. Nefropatia toczniowa manifestuje się białkomoczem, podwyższonym stężeniem kreatyniny w surowicy. Stwierdza się obecność leukocytów i erytrocytów oraz wałeczków szklistych lub ziarnistych w osadzie moczu. Ponadto u chorych może rozwinąć się zespół nerczycowy. Dodatkowo mogą towarzyszyć objawy świadczące o aktywnym TRU, takie jak spadek składowych dopełniacza oraz wzrost miana przeciwciał anty-dsDNA w surowicy [5]. Patogeneza nefropatii toczniowej jest związana z wytwarzaniem przeciwciał skierowanych przeciw własnym antygenom; wskazuje się głównie na przeciwciała anty-dsDNA. Do uszkodzenia nerek dochodzi poprzez reakcję autoprzeciwciał z antygenami kłębuszków nerkowych oraz tworzeniem odkładających się tam kompleksów immunologicznych [5]. Przeciwciałom anty-dsDNA przypisuje się znaczenie diagnostyczne i prognostyczne; mogą być wykorzystane do monitorowania aktywności choroby, szczególnie w przewidywaniu zbliżającego się zaostrzenia [4]. Ponadto wykazano, że występowanie przeciwciał anty-dsDNA, anty-Sm oraz antykoagulantu toczniowego (lupus anticoagulant) jest czynnikiem predysponującym do zajęcia nerek w przebiegu TRU [4].

\section{ZAJĘCIE SKÓRY}

W przebiegu TRU występuje szerokie spektrum objawów ze strony skóry takie jak: rumień w kształcie motyla na twarzy, rumień krążkowy, nadwrażliwość na światło czy owrzodzenia w jamie ustnej [7]. Zmiany skórne u chorych na TRU występują bardzo często, nawet u 70\% chorych i nasilają się po ekspozycji na światło ultrafioletowe (UV). Zmiany skórne można sklasyfikować jako ostry toczeń skórny (acute cutaneous lupus erythematosus - ACLE), podostry toczeń skórny (subacute cutaneous lupus erythematosus - SCLE), przewlekły toczeń skórny (chronic cutaneous lupus erythematosus - CCLE) oraz zmiany nieswoiste.

Ostry toczeń skórny najczęściej manifestuje się w postaci zmian plamisto-grudkowych i klasycznego rumienia w kształcie motyla na twarzy. Często u chorych z ACLE występują przeciwciała przeciwjądrowe (anti-nuclear antibodies - ANA), anty-dsDNA, anty-Sm. Przeważnie w przebiegu ACLE oprócz manifestacji skórnych obecne są również objawy ze strony innych narządów i układów. Podostry toczeń skórny manifestuje się w postaci zmian skórnych o charakterze obrączkowym lub grudkowym. Chorzy z SCLE mają wysoki stopień nadwrażliwości na światło. Blisko u 70\% chorych występują przeciwciała anty-SS-A, a u 70-80\% występują przeciwciała ANA [7]. Przewlekły toczeń skórny obejmuje zmiany obrzękowe (tumid lupus), toczniowe zapalenie tkanki podskórnej (lupus panniculitis) oraz zmiany o typie rumienia krążkowego. W CCLE rzadko występują przeciwciała przeciwjądrowe, anty-dsDNA czy anty-Sm. Mogą natomiast występować niskie miana przeciwciał anty-SS-A [7]. Dodatkowo mogą też występować niespecyficzne zmiany skórne takie jak: objaw Raynauda, siność siatkowata (livedo reticularis), leukocytoklastyczne zapalenie naczyń czy łysienie. W patogenezie zmian skórnych w przebiegu TRU wskazuje się na rolę promieniowania UV, apoptozy keratynocytów, uwalniania cytokin prozapalnych, nadmiernej aktywności limfocytów B i aktywacji limfocytów T oraz komórek dendrytycznych [7].

\section{ZAJĘCIE NARZĄDU RUCHU}

Zajęcie stawów u chorych na TRU jest powszechne i występuje u blisko 90\% chorych. Dotyczy głównie stawów kolanowych, nadgarstkowych oraz drobnych stawów rąk. Najczęstszym objawem zajęcia stawów w TRU jest artralgia - nawracający, migrujący ból stawów, w przebiegu którego nie stwierdza się cech jawnego zapalenia błony maziowej. Jednakże u chorych z tkliwością stawów badanie ultrasonograficzne może ujawnić 
wcześniej niewykryte zapalenie stawów, a także ścięgien. U chorych z zajęciem stawów może dochodzić do symetrycznego zapalenia wielu stawów wraz z ich obrzękami, ale nie stwierdza się zmian deformacyjnych, natomiast mogą występować zmiany nadżerkowe [8]. Chorzy dobrze odpowiadają na leczenie i u niewielkiego odsetka z nich (ok. 5\%) rozwija się trwała deformacja stawów - artropatie Jaccouda [9]. Dodatkowo mogą wystąpić bóle mięśni, z ostrym zapaleniem mięśni włącznie.

\section{ZAJĘCIE NARZĄDU WZROKU}

W przebiegu TRU może dojść do zajęcia wielu struktur oka, nerwu wzrokowego, przydatków oka, a także ośrodków wzroku w obrębie ośrodkowego układu nerwowego (OUN). Częstość i przebieg różnią się w zależności od zajętej struktury. Najczęstszym objawem u osób z zajęciem narządu wzroku jest zespół suchego oka, który stwierdza się nawet u co trzeciego chorego [10]. Skutkiem zespołu suchego oka mogą być owrzodzenie i bliznowacenie rogówki, a także pogorszenie ostrości widzenia $[10,11]$. U chorych stwierdza się retinopatię siatkówkową z częstością ok. 30\%, u podstaw której leżą zaburzenia o charakterze naczyniowym (krwotoki podsiatkówkowe, objaw kłębu waty, neowaskularyzacja, zapalenie naczyń oka) mogące skutkować nawet utratą wzroku (55\% przypadków) [12]. Zapalenie gałki ocznej oraz naczyń oka może skutkować utratą wzroku z powodu niedokrwienia nerwu wzrokowego i wzrostu ciśnienia wewnątrzgałkowego. W patogenezie zajęcia narządu wzroku w TRU wymienia się takie czynniki, jak odkładanie się kompleksów immunologicznych w zajętych tkankach i naczyniach, aktywację dopełniacza oraz zakrzepicę naczyń narządu wzroku [11, 12]. Zajęcie zewnętrznych struktur narządu wzroku nie jest częste, ale może objawiać się poprzez zapalenia naczyń i mięśni oka oraz obrzęk [10].

\section{ZAJĘCIE UKŁADU ODDECHOWEGO}

Objawy zajęcia układu oddechowego w przebiegu TRU występują u 40-50\% chorych. Jednakże w materiale sekcyjnym stwierdza się zmiany histologiczne charakterystyczne dla TRU niemalże w każdym przypadku. Zajęcie układu oddechowego stanowi negatywny czynnik rokowniczy i koreluje z aktywnością choroby [13, 14]. Może dotyczyć każdej części układu oddechowego. Proces zapalny może obejmować opłucną, drogi oddechowe, miąższ i naczynia płucne oraz mięśnie oddechowe [14]. Najczęściej zajęcie układu oddechowego manifestuje się w postaci zapalenia opłucnej (30-50\% chorych) [15]. Znacznie rzadziej stwierdza się zmiany w obrębie miąższu płuc pod postacią ostrego toczniowego zapalenia płuc (acute lupus pneumonitis) i przewlekłego śródmiąższowego włóknienia płuc. Zajęcie układu oddechowego w przebiegu TRU może manifestować się również w postaci zatorowości płucnej, rozlanego krwawienia pęcherzykowego, ostrej odwracalnej hipoksemii czy zespołu kurczących się płuc [16].

\section{ZAJĘCIE NACZYŃ}

Zajęcie naczyń u chorych na TRU objawia się ich zapaleniem, które cechuje naciek ściany naczynia przez komórki zapalne, a to w konsekwencji prowadzi do martwicy zajętego naczynia [17]. Zapalenie naczyń jest główną przyczyną zgonów wśród chorych na TRU [18]. Proces zapalny obejmujący naczynia może przybierać różne formy w zależności od kalibru zajętych naczyń (tętnice, żyły, kapilary) oraz miejsca wystąpienia (naczynia skórne lub narządów wewnętrznych) [19]. Zapalenia naczyń mogą przybierać postać od łagodnych aż po zagrażające życiu. Częstość występowania zapaleń naczyń u chorych na TRU podaje się w przedziale 11-36\% [19]. Epizody zapalenia naczyń mają często miejsce podczas zaostrzenia TRU wraz z objawami takimi jak gorączka, zmęczenie, obniżenie masy ciała [20]. Również częściej występują zmiany skórne w postaci siności siatkowatej (livedo reticularis), ponadto niedokrwistość, przyspieszone OB oraz często stwierdza się obecność przeciwciał anty-SS-B [19]. Epizod zapalenia naczyń może się rozwinąć na skutek odkładania się kompleksów immunologicznych w ścianie naczynia, ale również wskazuje się na rolę przeciwciał przeciwko komórkom śródbłonka (antiendothelial cell antibodies - AECA), które prowadzą do ich bezpośredniego uszkodzenia [21]. Obecność przeciwciał AECA stwierdza się nawet u $80 \%$ chorych na TRU [22]. Inne, istotne dla zapalenia naczyń są przeciwciała przeciwko cytoplazmie granulocytów obojętnochłonnych (antineutrophil cytoplasmic antibodies ANCA), które odgrywają główną rolę w pierwotnych układowych zapaleniach naczyń. U chorych na TRU stwierdza się obecność przeciwciał ANCA z częstością blisko 20\% [19, 23].

\section{ZAJĘCIE UKŁADU NERWOWEGO}

Zajęcie układu nerwowego u chorych na TRU jest dosyć częste (37-90\% przypadków) i może przybierać bardzo zróżnicowany obraz [24]. Objawy neurologiczne i psychiatryczne obserwowane w przebiegu zajęcia układu nerwowego u chorych na TRU określa się mianem tocznia neuropsychiatrycznego. Występowanie objawów neuropsychiatrycznych w TRU koreluje z większą aktywnością choroby i większym uszkodzeniem narządowym [25]. W patogenezie zajęcia układu nerwowego u chorych na TRU wskazuje się na: uszkodzenie bariery krew-mózg, udział cytokin prozapalnych i autoprzeciwciał, zaburzenia naczyniowe prowadzące do uszkodzenia lub zamknięcia naczynia (np. zapalenie naczyń, zakrzepica związana z zespołem antyfosfolipidowym) oraz krwotoków, bezpośrednie uszkodzenie tkanki mózgowej przez stres oksydacyjny i zaburzenia układu neuroendokrynnego [26, 27]. Zajęcie ośrodkowego układu nerwowego jest częstsze, może przybierać postać zaburzeń poznawczych (55-80\% przypadków), bólu głowy (24-72\% przypadków), zaburzeń nastroju (14-57\% przypadków), drgawek (6-51\% przypadków) zespołów mózgowo-naczyniowych (5-18\% przypadków) [28]. Objawy zajęcia ośrodkowego układu nerwowego można podzielić na uogólnione (np. zaburzenia funkcji poznawczych, jałowe 
zapalenie opon mózgowo-rdzeniowych, zespół demielinizacyjny, bóle głowy oraz zespoły psychiatryczne) i ogniskowe (choroba naczyń mózgowych, drgawki, zaburzenia ruchowe, mielopatia). Objawy ogniskowe mogą mieć podłoże naczyniowe, natomiast uogólnione mogą być związane z uszkodzeniem neuronów przy udziale autoprzeciwciał i cytokin prozapalnych [29]. Wśród chorych z zajęciem układu nerwowego szacuje się, że 13,5\% ma zajęcie obwodowego układu nerwowego w postaci obwodowej polineuropatii sensorycznej $(38,7 \%$ przypadków), rzadziej mieszanej neuropatii - sensorycznej i motorycznej (18,8\% przypadków) [24].

\section{CYTOKINY A ZAJĘCIE NARZĄDOWE}

W ostatnich latach pojawiły się doniesienia dotyczące roli cytokin w patogenezie zajęcia różnych narządów. Podczas prowadzonych badań określona została rola wybranych cytokin w zajęciu układu oddechowego oraz OUN [30, 31]. Jednakże do tej pory nie jest w pełni jasne, które cytokiny są odpowiedzialne za nasilenie, a które za zmniejszenie odpowiedzi zapalnej, co mogłoby pomóc w ustaleniu związku z obrazem klinicznym [32].

\section{INTERLEUKINA 4}

Interleukina 4 (IL-4) jest wytwarzana głównie przez limfocyty Th pobudzone antygenem lub mitogenem, limfocyty NKT, jak i również przez komórki tuczne i bazofile. Obecność receptorów dla IL-4 można stwierdzić na: limfocytach T i B, monocytach, makrofagach, komórkach tucznych i wielu innych [33]. Interleukina 4 ma szerokie spektrum oddziaływania, m.in. wzmaga proliferację limfocytów T i B, wpływa na cytotoksyczność i fagocytozę makrofagów oraz stymuluje proces krwiotworzenia poprzez wzmaganie granulopezy i erytropoezy [33]. Interleukina 4 przyczynia się do wzmożonej produkcji przeciwciał klasy IgE, co przekłada się na wzmożenie reakcji zapalnych o charakterze odczynów alergicznych, np. astmy [34, 35]. Dowiedziono na modelu zwierzęcym TRU (myszy NZW X C57BL-6. Yaa), że wzmożona produkcja IL-4 przyczynia się do zahamowania uszkodzeń narządowych; w tym przypadku wykazano, że zapobiega rozwojowi toczniowego zapalenia kłębuszków nerkowych poprzez zmianę profilu produkowanych podklas przeciwciał IgG [36]. Pozwala to wysunąć wniosek, że IL-4 zapobiega rozwojowi odpowiedzi autoimmunologicznej i chroni przed powikłaniami związanymi z przebiegiem TRU [36]. Jednakże, pomimo ochronnego działania IL-4, Peng i wsp. [37] prowadząc badania na mysim modelu zwierzęcym, przypisują tej cytokinie również rolę w patogenezie tej choroby poprzez jej bezpośredni udział w rozwoju powinowactwa i swoistości autoprzeciwciał oraz stymulowaniu limfocytów T i B. W przypadku badania prowadzonego u chorych na TRU wykazano, że stosunek interleukiny 18 (IL-18) do interleukiny 4 koreluje dodatnio z aktywnością choroby wyrażonej za pośrednictwem skali SLEDAI [38]. Wzrost stosunku IL-18/IL-4 świadczy o zaburzeniu równowagi profilu cytokin i przyczynia się do rozwinięcia odpowiedzi zapalnej [38].

\section{INTERLEUKINA 7}

Interleukina 7 (IL-7), znana również jako limfopoetyna, jest wytwarzana przez zrębowe narządy limfatyczne, tj. szpik i grasicę. Interleukina 7 odgrywa bardzo istotną rolę w limfopoezie, wpływa na różnicowanie się tymocytów, jak i limfocytów proi pre-B. Obok IL-4 jest jednym z czynników różnicowania limfocytów T cytotoksycznych. Ponadto IL-7 indukuje wytwarzanie cytokin prozapalnych przez monocyty [39]. Obecnie istnieją pojedyncze doniesienia dotyczące roli IL-7 w TRU. W jednej z publikacji autorstwa Gonzalez-Quintial i wsp. [40] odnotowano podwyższone stężenia IL-7 w surowicy myszy szczepu MRL-Faslpr, co związane było z ekspansją fibroblastów, które produkowały IL-7. Podwyższone stężenia IL-7 wzmagały proliferację autoreaktywnych limfocytów T, natomiast blokada receptora dla IL-7 (IL-7Ra) skutecznie odwróciła proces chorobowy. Z kolei w surowicy chorych na TRU z nefropatią toczniową wykazano znacznie podwyższone stężenia rozpuszczalnego receptora dla IL-7, co korelowało również ze stopniem aktywności choroby wyrażonego w skali SLEDAI. Dodatkowo w pobranych bioptatach nerki zaobserwowano wzmożoną ekspresję IL-7Ra w okolicy naczyń nerkowych, co było związane z obecnością TNF- $\alpha$ w otaczających tkankach [41]. Według danych literaturowych podwyższone stężenia interleukiny 7 w surowicy chorych na TRU obserwuje się jako odpowiedź na limfopenię w przebiegu TRU [42]. Co ważne, interleukinie 7 przypisuje się rolę w ekspansji autoreaktywnych klonów limfocytów T oraz w rozwoju choroby [43]. W przypadku chorych na reumatoidalne zapalenie stawów obserwuje się znacznie wyższe stężenia IL-7 w płynie stawowym niż w surowicy, co prowadzi do przewlekłego zapalenia w obrębie zajętych stawów oraz ich destrukcji [44]. W pierwotnym zespole Sjögrena (PZS) wskazuje się na udział IL-7 w zajęciu ślinianek u chorych. W ślinie chorych na PZS stwierdzono znacznie wyższe stężenia IL-7 niż u osób zdrowych [45]. Podobne mechanizmy mogą mieć miejsce w przebiegu TRU, jednakże by potwierdzić tę hipotezę, konieczne będzie wykonanie dodatkowych badań.

\section{INTERLEUKINA 10}

Interleukina 10 (IL-10) jest wytwarzana przez pobudzone limfocyty T, szczególnie limfocyty T regulacyjne (Tr1) oraz Th2, jak również limfocyty B, monocyty, makrofagi, neutrofile oraz komórki tuczne. Rolą IL-10 jest hamowanie komórkowej odpowiedzi immunologicznej oraz odpowiedzi zapalnej. Odbywa się to poprzez m.in.: hamowanie wytwarzania cytokin przez limfocyty Th1, hamowanie wytwarzania pobudzonych limfocytów Th1, hamowanie wytwarzania przez makrofagi i monocyty cytokin oraz reaktywnych form tlenu. Blokowanie IL-10 dało pozytywne efekty w leczeniu TRU [46]. Badania wykazały, że stężenie IL-10 u chorych na TRU jest znacznie podwyższone 
w porównaniu z populacją ogólną i koreluje ze stopniem aktywności choroby (SLEDAI) [47] oraz z produkcją autoprzeciwciał [48]. Podobnie w przebiegu toczniowego zapalenia nerek obserwuje się wzrost stężeń IL-10 w porównaniu z grupą kontrolną [49]. Pomimo tego, że IL-10 ma zdolność do efektywnego wyciszania odpowiedzi immunologicznej oraz zapalnej, Yuan i wsp. [50] wykazali, że właściwości IL-10 do hamowania produkcji cytokin prozapalnych IL-6 i TNF- $\alpha$ zostają zniesione, przez co procesy autoimmunologiczne w przebiegu TRU się nasilają. Wykazano, że stosunek stężeń IL-8/IL-10 może stanowić wskaźnik zajęcia układu oddechowego u chorujących na TRU [31].

\section{INTERLEUKINA 18}

Interleukina 18 jest wytwarzana przez makrofagi, komórki nabłonkowe oraz keratynocyty i osteoblasty. Wywiera działanie na różne populacje limfocytów T i komórek NK. Jest kluczowym aktywatorem limfocytów Th1, ale również ma zdolność do indukowania wytwarzania cytokin przez limfocyty Th2. Cytokina ta wzmaga wytwarzanie przez wspomniane komórki cytokin prozapalnych, m.in. IFN- $\gamma$, TNF- $\alpha$, wzmaga cytotoksyczność limfocytów T CD8 ${ }^{+}$, komórek NK oraz limfocytów $\mathrm{CD}_{4}{ }^{+}$. Poprzez swoje działanie IL-18 przyczynia się do rozwoju zapalenia i w konsekwencji do uszkodzenia tkanek i narządów. Ponadto może wzmagać wytwarzanie IL-4 i IL-13 [51, 52]. W surowicy chorych na TRU stwierdza się znacznie wyższe stężenie IL-18 niż w grupie kontrolnej [53, 54, 55]. Wykazano także statystycznie istotną dodatnią korelację pomiędzy stężeniem IL-18 w surowicy chorych a stopniem aktywności choroby mierzonym za pomocą skali SLEDAI oraz mianem przeciwciał anty-dsDNA [53]. Dodatkowo znacznie wyższe stężenia IL-18 odnotowano u chorych na TRU z zajęciem nerek w porównaniu z chorymi bez zajęcia nerek. Najwyższe stężenia IL-18 wykryto u chorych z nefropatią toczniową manifestującą się jako rozlane rozplemowe lub błoniastorozplemowe kłębuszkowe zapalenie nerek (klasa IV i V według klasyfikacji WHO) [55]. Uznaje się obecność IL-18 w moczu jako wskaźnik przebiegającego toczniowego zapalenia nerek zarówno u ludzi, jak i w modelach zwierzęcych [56]. Dodatkowo Tso i wsp. [57] wykazali, że wzrastające stężenie IL-18 w surowicy chorych na TRU jest związane ze wzrostem ryzyka sercowo-naczyniowego. Podwyższone stężenie IL-18 w przebiegu TRU przyczynia się do dysfunkcji progenitorowych komórek śródbłonka, co przekłada się na upośledzenie naczyniowych mechanizmów naprawczych [58]. Jednakże jak podaje Panafidina i wsp. [59], stężenie IL-18 nie ma związku z zapaleniem naczyń w przebiegu tej choroby. Oprócz tego IL-18 przypisuje się rolę w zajęciu skóry w przebiegu TRU. W wycinkach skóry chorych na TRU stwierdzono wyższe stężenia IL-18 niż w tych pobranych od osób zdrowych. Szczególnie istotny jest fakt, że keratynocyty wyizolowane z wycinków skóry chorych na TRU po stymulacji IL-18 wzmagały wytwarzanie TNF- $\alpha$ oraz wykazywały znacznie większą tendencję do apoptozy niż keratynocyty wyizolowane z materiału pochodzącego od osób zdrowych [6o].

\section{PIŚMIENNICTWO}

1. Gatto M, Zen M, Ghirardello A, Bettio S, Bassi N, Iaccarino L, et al. Emerging and critical issues in the pathogenesis of lupus. Autoimmun Rev 2013;12(4):523-36.

2. Ceccarelli F, Perricone C, Borgiani P, Ciccacci C, Rufini S, Cipriano E, et al. Genetic factors in systemic lupus erythematosus: contribution to disease phenotype. J Immunol Res 2015;2015:745647. doi: 10.1155/2015/745647.

3. Han S, Zhuang H, Shumyak S, Yang L, Reeves WH. Mechanisms of autoantibody production in systemic lupus erythematosus. Front Immunol 2015;6:228.

4. Alba P, Bento L, Cuadrado MJ, Karim Y, Tungekar MF, Abbs I, et al. AntidsDNA, anti-Sm antibodies, and the lupus anticoagulant: significant factors associated with lupus nephritis. Ann Rheum Dis 2003;62:556-60.

5. Imran TF, Yick F, Verma S, Estiverne C, Ogbonnaya-Odor C, Thiruvarudsothy S, et al. Lupus nephritis: an update. Clin Exp Nephrol 2015;20(1):1-13.

6. Ortega LM, Schultz DR, Lenz O, Pardo V, Contreras GN. Review: lupus nephritis: pathologic features, epidemiology and a guide to therapeutic decisions. Lupus 2010;19(5):557-74.

7. Robinson ES, Werth VP. The role of cytokines in the pathogenesis of cutaneous lupus erythematosus. Cytokine 2015;73(2):326-34.

8. Ball EMA, Bell AL. Lupus arthritis - do we have a clinically useful classification? Rheumatology 2012;51(5):771-9.

9. Lins CF, Santiago MB. Ultrasound evaluation of joints in systemic lupus erythematosus: a systematic review. Eur Radiol 2015;25(9):2688-92.

10. Preble JM, Silpa-archa S, Foster CS. Ocular involvement in systemic lupus erythematosus. Curr Opin Ophthalmol 2015;26(6):540-5.

11. Read RW. Clinical mini-review: systemic lupus erythematosus and the eye. Ocul Immunol Inflamm 2004;12:87-99.

12. Talat L, Lightman S, Tomkins-Netzer O. Ischemic retinal vasculitis and its management. J Ophthalmol 2014;2014:197675. doi: 10.1155/2014/197675.

13. Goh NS. Connective tissue disease and the lung. Clin Pulm Med 2009;16:309-14.

14. Nielepkowicz-Goździńska A, Fendler W, Robak E, Kulczycka-Siennicka L, Górski P, Pietras T, et al. Exhaled cytokines in systemic lupus erythematosus with lung involvement. Pol Arch Med Wewn 2013;123(4):141-8.

15. Pines A, Kaplinsky N, Olchovsky D, Rozenman J, Frankl O. Pleuro-pulmonary manifestations of systemic lupus erythematosus: clinical features of its subgroups. Prognostic and therapeutic implications. Chest 1985;88:129-35.

16. Starczewska MH, Wawrzyńska L, Opoka L, Małek G, Wieliczko M, Amatuszkiewicz-Rowińska J, et al. Acute lupus pneumonitis - case report and literature review. Pneumonol Alergol Pol 2013;81(5):460-7.

17. Doyle M. Vasculitis associated with connective tissue disorders. Curr Rheumatol Rep 2006;8:312-6.

18. Pyrpasopoulou A, Chatzimichailidou S, Aslanadis S. Vascular disease in systemic lupus ery thematosus. Autoimmune Dis 2012;2012:876456. doi: 10.1155/2012/876456.

19. Barile-Fabris L, Hernández-Cabrera MF, Barragan-Garfias JA. Vasculitis in systemic lupus erythematosus. Curr Rheumatol Rep 2014;16(9):440.

20. Ramos-Casals M, Nardi N, Lagrutta M, Brito-Zerón P, Bové A, Delgado G, et al. Vasculitis in systemic lupus erythematosus: Prevalence and Clinical Characteristics in 670 patients. Medicine 2006;85:95-104.

21. Ciéslik P, Hrycek A, Kłucinski P. Vasculopathy and vasculitis in systemic lupus erythematosus. Pol Arch Med Wewn 2008;118(1-2):57-63.

22. Guilpain P, Mouthon L. Antiendothelial cells autoantibodies in vasculitisassociated systemic diseases. Clin Rev Allergy Immunol 2008;35(1):59-65.

23. Galeazzi M, Morozzi G, Sebastiani GD, Bellisai F, Marcolongo R, Cervera R, et al. Antineutrophil cytoplasmic antibodies in 566 European patients with systemic lupus erythematosus: prevalence, clinical associations and correlation with other autoantibodies. Clin Exp Rheumatol 1998;16(5):541-6.

24. Florica B, Aghdassi E, Su J, Gladman DD, Urowitz MB, Fortin PR. Peripheral neuropathy in patients with systemic lupus ery thematosus. Semin Arthritis Rheum 2011;41:203-11.

25. Wang M, Gladman DD, Ibańez D, Urowitz MB. Long-term outcome of early neuropsychiatric events due to active disease in systemic lupus erythematosus. Arthritis Care Res 2012;64:833-7.

26. Rhiannon JJ. Systemic lupus erythematosus involving the nervous system: presentation, pathogenesis, and management. Clin Rev Allergy Immunol 2008;34:356-60 
27. Jeltsch-David H, Muller S. Neuropsychiatric systemic lupus erythematosus: pathogenesis and biomarkers. Nat Rev Neurol 2014;10(10):579-96. doi: 10.1038/nrneurol.2014.

28. Brey RL, Holliday SL, Saklad AR, Navarrete MG, Hermosillo-Romo D, Stallworth CL, et al. Neuropsychiatric syndromes in lupus: Prevalence using standardized definitions. Neurology 2002;58(8):1214-20.

29. ACR ad hoc committee on neuropsychiatric lupus nomenclature. The American College of Rheumatology nomenclature and case definitions for neuropsychiatric lupus syndromes. Arthritis Rheum 1999;42(4):599-608.

30. Santer DM, Yoshio T, Minota S, Möller T, Elkon KB. Potent induction of IFN-alpha and chemokines by autoantibodies in the cerebrospinal fluid of patients with neuropsychiatric lupus. J Immunol 2009;15;182(2):1192-201.

31. Al-Mutairi S, Al-Awadhi A, Raghupathy R, Al-Khawari H, Sada P, Al-Herz A, et al. Lupus patients with pulmonary involvement have a pro-inflammatory cytokines profile. Rheumatol Int 2007;27(7):621-30.

32. Lauwerys BR, Houssiau FA. Involvement of cytokines in the pathogenesis of systemic lupus erythematosus. Adv Exp Med Biol 2003;520:237-51.

33. Zhu J. T helper 2 (Th2) cell differentiation, type 2 innate lymphoid cell (ILC2) development and regulation of interleukin-4 (IL-4) and IL-13 production. Cytokine 2015;75(1):14-24.

34. Wills-Karp M, Luyimbazi J, Xu X. Interleukin-13: central mediator of allergic asthma. Science 1998;282:2258-60.

35. Walsh GM. Anti-IL-4/-13 based therapy in asthma. Expert Opin Emerg Drugs 2015;20(3):349-52.

36. Santiago ML, Fossati L, Jacquet C, Müller W, Izui S, Reininger L. Interleukin-4 protects against a genetically linked lupus-like autoimmune syndrome. J Exp Med 1997;185(1):65-70.

37. Peng SL, Moslehi J, Craft J. Roles of interferon-gamma and interleukin-4 in murine lupus. J Clin Invest 1997;15;99(8):1936-46.

38. Wong CK, Ho CY, Li EK, Lam CW. Elevation of proinflammatory cytokine (IL-18, IL-17, IL-12) and Th2 cytokine (IL-4) concentrations in patients with systemic lupus erythematosus. Lupus 2000;9(8):589-93.

39. Dooms H. Interleukin-7: Fuel for the autoimmune attack. J Autoimmun 2013;45:40-8

40. Gonzalez-Quintial R, Lawson BR, Scatizzi JC, Craft J, Kono DH, Baccala R, et al. Systemic autoimmunity and lymphoproliferation are associated with excess IL-7 and inhibited by IL-7R $\alpha$ blockade. PLoS One 2011;6(11): e27528.

41. Badot V, Luijten RK, van Roon JA, Depresseux G, Aydin S, Van den Eynde BJ, et al. Serum soluble interleukin 7 receptor is strongly associated with lupus nephritis in patients with systemic lupus erythematosus. Ann Rheum Dis 2013;72(3):453-6.

42. Ponchel F, Cuthbert RJ, Goëb V. IL-7 and lymphopenia. Clin Chim Acta 2011;412(1-2):7-16. doi: 10.1016/j.cca.2010.09.002.

43. Lundström W, Fewkes NM, Mackall CL. IL-7 in human health and disease. Semin Immunol 2012;24(3):218-24.

44. Churchman S, Ponchel F. Interleukin-7 in rheumatoid arthritis. Rheumatology (Oxford) 2008;47(6):753-59.

45. Kabeerdoss J, Sandhya P, Mandal SK, Gowri M, Danda D. High salivary soluble L-selectin and interleukin-7 levels in Asian Indian patients with primary Sjögren's syndrome. Clin Rheumatol 2016;35(12):3063-7.
46. Saxena A, Khosraviani S, Noel S, Mohan D, Donner T, Hamad AR. Interleukin-10 paradox: A potent immunoregulatory cytokine that has been difficult to harness for immunotherapy. Cytokine 2015;74(1):27-34.

47. Park YB, Lee SK, Kim DS, Lee J, Lee CH, Song CH. Elevated interleukin-10 levels correlated with disease activity in systemic lupus erythematosus. Clin Exp Rheumatol 1998;16(3):283-8.

48. Liu TF, Jones BM. Impaired production of IL-12 in system lupus erythematosus. II: IL-12 production in vitro is correlated negatively with serum IL-10, positively with serum IFN-gamma and negatively with disease activity in SLE. Cytokine 1998;10(2):148-53.

49. Zhi-Chun L, Qiao-Ling Z, Zhi-Qin L, Xiao-Zhao L, Xiao-xia Z, Rong T. Tumor necrosis factor-like weak inducer of apoptosis (TWEAK) mediates p38 mitogen-activated protein kinase activation and signal transduction in peripheral blood mononuclear cells from patients with lupus nephritis. Inflammation 2012;35(3):935-43.

50. Yuan W, DiMartino SJ, Redecha PB, Ivashkiv LB, Salmon JE. Systemic lupus erythematosus monocytes are less responsive to interleukin-10 in the presence of immune complexes. Arthritis Rheum 2011;63(1):212-8.

51. Jafari-Nakhjavani MR, Abedi-Azar S, Nejati B. Correlation of plasma interleukin-18 concentration and severity of renal involvement and disease activity in systemic lupus erythematosus. J Nephropathol 2016;5(1):2833. doi: 10.15171/jnp.2016.05.

52. Favilli F, Anzilotti C, Martinelli L, Quattroni P, De Martino S, Pratesi F, et al. IL-18 activity in systemic lupus erythematosus, contemporary challenges in autoimmunity. Ann N Y Acad Sci 2009;1173:301-9.

53. Park MC, Park YB, Lee SK. Elevated interleukin-18 levels correlated with disease activity in systemic lupus erythematosus. Clin Rheumatol 2004;23:225-9.

54. Wong CK, Lit LC, Tam LS, Li EK, Lam CW. Elevation of plasma interleukin-18 concentration is correlated with disease activity in systemic lupus erythematosus. Rheumatology (Oxford) 2000;39:1078-81.

55. Wong CK, Ho CY, Li EK, Tam LS, Lam CW. Elevated production of interleukin-18 is associated with renal disease in patients with systemic lupus erythematosus. Clin Exp Immunol 2002;130:345-51.

56. Migliorini P, Anzilotti C, Pratesi F, Quattroni P, Bargagna M, Dinarello CA, et al. Serum and urinary levels of IL-18 and its inhibitor IL-18BP in systemic lupus erythematosus. Eur Cytokine Netw 2010;21(4):264-71.

57. Tso TK, Huang WN, Huang HY, Chang CK. Relationship of plasma interleukin-18 concentrations to traditional and non-traditional cardiovascular risk factors in patients with systemic lupus erythematosus. Rheumatology (Oxford) 2006;45(9):1148-53.

58. Kahlenberg JM, Thacker SG, Berthier CC, Cohen CD, Kretzler M, Kaplan MJ. Inflammasome activation of IL-18 results in endothelial progenitor cell dysfunction in systemic lupus erythematosus. J Immunol 2011;187(11):6143-56.

59. Panafidina TA, Popkova TV, Alekberova ZS, Mach ES, Aleksandrova EN, Nasonov EL. Interleukin-18 in systemic lupus erythematosus: link with clinical symptoms and vascular atherosclerosis. Ter Arkh 2008;80(5):41-6.

60. Wang D, Drenker M, Eiz-Vesper B, Werfel T, Wittmann M. Evidence for a pathogenetic role of interleukin-18 in cutaneous lupus erythematosus. Arthritis Rheum 2008;58:3205-15. 